\section{Eton College Natural History Society}

THE report of the Eton College Natural History Society for 1955-57 (pp. 52. Eton College, 1957. 2s. 6d.) shows that, during the past two years, there has been an increased number of moetings addressed by speakers expert in their particular fields. In field-work, however, the Society has not been as active as in former years. "A few boys," writes the editor plaintively, "interested in butterflies and birds go on the expeditions with serious intention, but the majority wander aimlessly with no real object." Among the contributions by boys is an article by C. J. Fisher, describing observations made on St. Kilda; an account of a butterfly holiday in Wiltshire by H. M. L. Wade; as well as descriptions of butterflies seen by J. A. Lumley during successive periods of 1956.

\section{Drum Types of Eastern New Guinea}

AN important publication of the National Museum of Victoria (Memoirs, No. 22, Part 7 (4th September, 1957) : Drum Types of Eastern New Guinea. By Aldo Massola. Pp. 12 (2 plates). Melbourne : National Museum of Victoria, 1957) describes the types of drums from eastern New Guinea. The drums are classified either as with or without handles and an intermediate class of half-handle or elbow. A separate division includes those made of bamboo. The drums are fully described, and with adequate illustrations this paper forms a useful means of identifying such material in ethnographical collections.

\section{Pests in Stored Products}

THE importance of stored products infestation is to-day widely recognized. The international nature of this problem is demonstrated by a report recently published (Control of Pests in Stored Agricultural Products with Special Reference to Grain. (Project No. 212.) Pp. 169. Paris : European Productivity Agency of the Organization for European Economic Co-operation; London: H.M. Stationery Office, 1958. 700 French francs; 11s. 6d.; 2 dollars) of a survey the ultimate aim of which was "to ensure that imports of human and animal food arrive in Europe free from active infestation by insects and mites and with the minimum of damage caused by their attacks". The survey lasted eight months and covered North and South America and certain countries in North Africa and the eastern Mediterranean area. It was undertaken by Dr. J. A. Freeman, of the Infestation Control Division of the Ministry of Agriculture, Fisheries and Food, who also wrote the report. He was assisted for part of the time in North America by Dr. Sevelin, of the German Federal Ministry for Food, Agriculture and Forestry. The report is comprehensive, giving factual information concerning the trade practices, pest control organization and the general level of infestation in the countries visited. A large section is devoted to recommendations for future action; these in turn deal with scientific techniques and the furtherance of technical collaboration between different countries, and with the much more difficult and controversial problems posed by certain established practices in international trade. This is perhaps the most valuable feature of the report, in that it clearly points out that the problem of stored food infestation is not one that can be solved by the scientist alone, but requires the active co-operation of the food-handling industry on a fully international basis.

\section{Silicified Permian Fossils from Texas and New Mexico}

THE problem of extracting fossils preserved in hard, adherent rock matrix is readily solved when the fossils consist of siliceous pseudomorphs of the hard parts of the original organisms while the matrix remains unaltered limestone. American palæontologists are exceptionally fortunate in the wealth of material available to them preserved in this manner. During the past fifteen years some 60 tons of Permian limestones from the south-western States have been transported to Washington and New York and their fossil contents etched out by the action of hydrochloric acid. Among the vast number of invertebrate fossils thus isolated are remarkably preserved brachiopods, of which G. Arthur Cooper has so far given merely a preliminary account. The gastropods are being described in a series of monographs in the Bulletin of the American Museum of Natural History. The first of these, by E. L. Yochelson, was published in 1956 (110; art. 3 ), while the second (114; art. 2$)$, by Prof. R. L. Batten, who deals with the Pleurotomariacea, has recently appeared (pp. 153-246+ plates 32-42. New York: American Museum of Natural History. 1958. 3 dollars). The state of preservation of the etched-out fossils is such that it has been possible to illustrate the finest details of ornament, while the amount of material is so great that Prof. Batten has been able to make elaborate statistical studies of the various species, probably for the first time in the case of pre-Tertiary gastropods. The work that is being carried out by these American authorities is a most notable contribution to our knowledge of the invertebrate life of Upper Palæozoic seas.

\section{Extraction of Helium from Gas Mixtures}

DuRnNG the Fifth International Conference on Low Temperature Physies and Chemistry, held at Madison, Wisconsin, in 1957, concern was expressed because at present only a small proportion of helium is extracted from the considerable volume of heliumrich natural gas that is used as a fuel, so that a large proportion of our limited helium resources is being wasted. There will therefore be considerable interest in a new and simple method of extracting helium that is being developed by K. B. McAfee, of the Bell Telephone Laboratories. The method makes use of the fact that, under a high pressure difference, helium, but not other gases, will diffuse fairly rapidly through a thin wall of silica or 'Pyrex' glass, especially if the glass is at a high temperature. In a practical arrangement, the mixture containing helium is passed around the outside of a large number of glass capillaries of 0.002 in. external diameter and 0.0002 in. wall thickness, and the helium is extracted from inside the capillaries. With a pressure difference of 1,000 atmospheres, a practical cell containing capil. laries occupying a volume of about $2 \mathrm{cu}$. yd. could extract from a 1 per cent mixture about $1,000 \mathrm{cu}$. $\mathrm{ft}$. of helium per day at room temperature and about $100,000 \mathrm{cu}$. ft. at $400^{\circ} \mathrm{C}$. It is suggested that all the helium-rich natural gas that is collected could exsily be passed through such cells. The resulting helium is very pure, and the process could also be used simply for purification.

\section{Indian Society for Plant Physiology}

During August 1957 plant physiologists from all parts of India met at the University of Delhi to 